\title{
PENGELOLAAN DANA DESA DALAM BIDANG PEMBERDAYAAN (STUDI KASUS DESA NEKBAUN, KECAMATAN AMARASI BARAT, KABUPATEN KUPANG
}

\author{
Anthon Simon Yohanis Kerihi \\ Fakultas Eknomi dan Bisnis Universitas Nusa Cendana \\ kerihi@yahoo.com
}

\begin{abstract}
Abstract: This study aims to identify and explain how the village fund management in 2018 in the field of empowerment. This will certainly be adjusted based on the Minister of Home Affairs Regulation No. 113 of 2014 concerning Village Financial Management. This research uses qualitative method with interview technique and field documentation on 14 informants as key informants who are trusted to know about village financial management starting from the planning, budgeting, implementation, administration, reporting and accountability stages. The results of the study found that the existence of programs that had not been implemented or carried out well such as BUMDES and Taman Eden due to village fund management in the field of empowerment had not applied the principles of transparency, accountability, participants, and obedience and budget discipline in a good and correct manner. This is caused by several things including; lack of understanding from village officials regarding village fund management, especially in the area of empowerment, lack of level of community participation also in program implementation, lack of supervision from the district or provincial level also causes village governments to neglect in carrying out their duties and responsibilities, lack of training and socialization as one of the obstacles in the village fund management process, on the other hand, there are individuals who want to take advantage of funds sourced from the $A P B N$, and the latter is a classic problem found in almost every village. Human power is less qualified due to the small number of people who have tertiary education.
\end{abstract}

Keywords: Village Fund, Village Fund Management, Empowerment Sector.

\section{PENDAHULUAN}

Undang-Undang Nomor 6 Tahun 2014 tentang Desa, yang selanjutnya didukung dengan Peraturan Pemerintah Nomor 60 tahun 2014 tentang Dana Desa yang bersumber dari Anggaran Pendapatan Belanja Negara. Anggaran tersebut diperuntukkan bagi desa yang ditransfer melalui APBD kabupaten/kota dan digunakan untuk membiayai penyelenggaraan pemerintahan, pelaksanaan pembangunan, pembinaan kemasyarakatan, dan pemberdayaanmasyarakat.Indonesia merupakan negara dengan jumlah provinsi sebanyak 34 dengan 415 kabupaten dan 93 kota. Indonesia menganut sistem otonomi daerah dimana setiap daerah harus mampu mengelola keuangannya sendiri demi memenuhi kebutuhannya masingmasing. Indonesia memiliki 542 daerah otonom yang memiliki tanggung jawab bagi daerahnya masing-masing. Kebijakan tentang Dana Desa yang bersumber dari APBN menurut Peraturan Pemerintah Nomor 60 memberikan tanggungjawab besar bagi pemerintah desa untuk berdikari dalam membangun desanya dengan lebih baiklagi.
Pada tahun 2016, Direktorat Pembangunan dan Pemberdayaan Masyarakat Desa telah mengeluarkan Permendes No. 21 Tahun 2016 tentang Penetapan Prioritas Penggunaan Dana Desa Tahun 2016, yang dapat dijadikan sebagai acuan bagi desa dalam menentukan program dan prioritas pembangunan desa yang meliputi: (a) pembangunan, pengembangan, dan pemeliharaan infrasruktur atau sarana dan prasarana fisik untuk penghidupan, termasuk ketahanan pangan dan permukiman; (b) pembangunan, pengembangan dan pemeliharaan sarana dan prasarana kesehatan masyarakat; (c).pembangunan, pengembangan dan pemeliharaan sarana dan prasarana pendidikan, sosial dan kebudayaan; (d) pengembangan usaha ekonomi masyarakat, meliputi pembangunan dan pemeliharaan sarana prasarana produksi dan distribusi; atau (e) pembangunan dan pengembangan sarana-prasarana energi terbarukan serta kegiatan pelestarian lingkunganhidup.

Desa Nekbaun merupakan salah satu desa yang terletak di Kecamatan Amarasi Barat, Kabupaten Kupang. Peneliti memilih Desa Nekbaun sebagai tempat penelitian karena dianggap memiliki masalah dalam pengelolaan dana desa. Desa Nekbaun menjadi salah satu desa yang juga sudah menerima aliran Dana Desa sejak 
disahkannya Undang-Undang Nomor 6 Tahun 2014 tentang Desa dan Peraturan Pemerintah Nomor 60 tahun 2014 tentang Dana Desa yang Bersumber dari APBN.

Dana Desa sejak disahkannya Undang-
Undang Nomor 6 Tahun 2014 tentang Desa dan Peraturan Pemerintah Nomor 60 tahun 2014 tentang Dana Desa yang Bersumber dari APBN. Berikut disajikan data mengenai APBDes Desa Nekbaun pada tabel 1

Tabel 1. Info APBDes Desa Nekbaun Tahun 2017

\begin{tabular}{|l|r|}
\hline \multicolumn{2}{|c|}{ Pendapata I Desa (Rp) } \\
\hline Pendapatan Asli Desa & $10.000 .000,-$ \\
\hline Dana Desa & $\mathbf{8 0 4 . 4 0 7 . 0 0 0 , -}$ \\
\hline Bagi Hasil Pajak & $3.925 .000,-$ \\
\hline Alokasi Dana Desa & $438.836 .000,-$ \\
\hline Silpa 2016 & $50.000 .000,-$ \\
$-\quad$ Kebun Desa (Taman Eden) & $24.662600,-$ \\
\hline$\quad$ Rehap Jembatan & $\mathbf{1 . 3 3 1 . 8 3 0 . 6 0 0 , -}$ \\
\hline Jumlah & \\
\hline
\end{tabular}

Sumber : Data APBDes Desa Nekbaun Tahun 2017

Data pada tabel 1. menunjukan bahwa sumber pendapatan desa dari Dana Desa merupakan sumber pendapatan desa terbesar yaitu Rp 804.407.000,-atau 60,4 persen dari keseluruhan pendapatan desa sebesar Rp 1.331.830.600,-. Dana Desa yang bersumber dari APBN ini diharapkan mampu memenuhi kebutuhan masyarakat Desa Nekbaun terutama pada bidang pembangunan dan pemberdayaan masyarakat.

Desa yaitu dalam Bidang Pembangunan dan Pemberdayaan dengan kontribusi yang cukup besar. Hal ini ditunjukan pada tabel 2.

Tabel 2. Data APBdes Desa Nekbaun dalam Bidang Pemberdayaan dan Pembangunan Desa

Tahun 2017

\begin{tabular}{|l|r|l|r|}
\hline \multicolumn{2}{|c|}{ Bidang Pembangunan (Rp) } & \multicolumn{2}{c|}{ Bidang Pemberdayaan (Rp) } \\
\hline $\begin{array}{l}\text { Pembangunan } \\
\text { Jalan Sirtu }\end{array}$ & $151.189 .300,-$ & $\begin{array}{l}\text { Pengadaan Ternak } \\
\text { Sapi }\end{array}$ & 250.000.000,- \\
\hline $\begin{array}{l}\text { Pembangunan } \\
\text { Jalan Tani }\end{array}$ & $55.454 .500,-$ & $\begin{array}{l}\text { Pendirian dan } \\
\text { Pembangunan } \\
\text { BUMDES }\end{array}$ & \\
\hline $\begin{array}{l}\text { Pembanngunan } \\
\text { Jalan Rabat }\end{array}$ & $37.671 .800,-$ & $\begin{array}{l}\text { Pengembangan Kebun } \\
\text { Desa }\end{array}$ & $52.150 .400,-$ \\
\hline Pembangunan Embung & 110.263 .100 & & $\mathbf{3 7 7 . 1 5 0 . 4 0 0}$ \\
\hline Jumlah & $\mathbf{3 5 4 . 5 7 8 . 7 0 0 , -}$ & Jumlah & \\
\hline
\end{tabular}

Sumber : Data APBDes Desa Nekbaun Tahun 2017

Pada Tabel 2. dapat dilihat dalam Bidang Pembangunan dialokasikan sebesar Rp 354.578.700,- atau 26,6 persen dari total jumlah pendapatan desa lebih kecil dari pada anggaran pada Bidang Pemberdayaan sebesar Rp 377.578.700,atau 28,3 persen dari jumlah pendapatan Desa Nekbaun Tahun 2017. Hal ini menunjukan bahwa bidang pemberdayaan merupakan fokus utama desa 
dalam meningkatkan pendapatan masyarakat desa agar tercapainya kesejahteraan masyarakat atau perubahan yang lebih baik kedepannya.

Bidang Pemberdayaan pada desa Nekbaun memiliki tiga program yang menjadi prioritas dalam upaya meningkatkan pendapatan bagi masyarakat diantaranya, pengadaan ternak sapi mengeluarkan anggaran yang cukup fantastis dari jumlah alokasi di bidang pemberdayaan yakni sebesar Rp 250.000.000,- atau 66,3 persen dan 18,7 persen kalau dihitung dari keseluruhan Pendapatan Desa. Anggaran sebesar ini digunakan untuk pengadaan ternak sapi sebanyak 50 ekor dengan perhitungan 1 ternak sapi mengeluarkan biaya sebesar 5 juta rupiah dan sudah termasuk didalamnya pengadaan tali, pengadaan obat dan vaksin, dan transportasi.

Bidang pemberdayaan juga memiliki sasaran lain yaitu pada Pendirian dan Pembangunan BUMDES sebesar Rp 75.000.000,dan Pengembangan Kebun Desa (Taman Eden) sebesar Rp. 52.150.400,- ditambah dengan SILPA Kebun Desa (Taman Eden) tahun 2017 sebesar Rp 50.000.000,-. Anggaran Pengembangan Kebun Desa (Taman Eden) inidigunakan untuk Belanja Barang dan Jasa dan Belanja Modal seperti pengadaan alat-alat pengolah pertanian dan juga pengadaan tanaman. Sementara pada Pendirian dan Pembangunan BUMDES pada tahun 2017 berdasarkan hasil wawancara pra penelitian yang dilakukan oleh peneliti terhadap Kepala Desa Nekbaun belumterealisasikan sehingga dananya sebesar Rp 75.000.000,- dikembalikan pada kopdit desa.Dengan demikian peneliti bertujuan untuk mengidentifikasi lebih dalam mengenai pengelolaan dana desa dalam bidang pemberdayaan di Desa Nekbaun, Kecamatan Amarasi Barat, Kabupaten Kupang, sesuai dengan Permendagri nomor 113 tahun2014 tentang Pengelolaan Keuangan Desa dan Permendagri nomor 114 tahun 2014 tentang Pedoman Pembangunan Desa yang dalam hal ini peneliti lebih terfokuskan dalam bidangpemberdayaan.

\section{KAJIAN PUSTAKA \\ Pengertian Desa}

Kata "desa" sendiri berasal dari bahasa India yakni "swadesi" yang berarti tempat asal, tempat tinggal, negeri asal, atau tanah leluhur yang merujuk pada satu kesatuan hidup, dengan satu kesatuan norma, serta memiliki batas yang jelas (Soetardjo, 1984:15, Yuliati, 2003:24).

\section{Karakteristik Desa}

Di Indonesia, wilayah yang disebut desa seharusnya dilihat dalam tahapan yang tidak sama. Masyarakat yang telah mulai menetap juga memiliki karakteristik yang berbeda-beda antara satu dengan yang lain, antara Jawa dengan luar Jawa, antara desa dekat kota dengan desa yang jauh dari kota, antara wilayah dataran tinggi dengan dataran rendah, demikian pula antara pantai dan pedalaman. Di Indonesia kelihatannya belum ada kajian mendalam tentang hal ini. Secara umum masyarakat yang telah mulai menetap yang disebut dengan desa, istilah sebutannya sangat beragam di berbagai suku bangsa.

\section{Pemerintah Desa}

Pemerintahan desa memiliki peranan signifikan dalam pengelolaan proses sosial dalam masyarakat. Terlebih dalam Penglolaan Keuangan Desa sebagaimana dimaksudkan dalam Permendagri nomor 113 tahun 2014 pasal 1 ayat (2)Pemerintahan Desa adalah penyelenggaraan urusan pemerintahan dankepentingan masyarakat setempat dalam sistem pemerintahan Negara Kesatuan RepublikIndonesia.Menurut UU No. 6 Tahun 2014 dalam pelaksanaan pemerintahan desa, kepala desa selaku pemerintah desa memiliki wewenang sebagai berikut:

a. Memimpin penyelenggaraan pemerintahan berdasarkan kebijakan yang ditetapkan bersama Badan Perwakilan Desa (BPD);

b. Mengangkat dan memberhentikan perangkat Desa;

c. Memegang kekuasaan pengelolaan keuangan dan aset Desa;

d. Menetapkan peraturan Desa;

e. Menetapkan anggaran dan belanja Desa;

f. Membina kehidupan masyarakat Desa;

g. Membina ketentraman dan ketertiban masyarakat Desa;

h. Mengembangkan sumber pendapatan Desa;

i. Mengusulkan dan menerima pelimpahan sebagian kekayaan Negara guna meningkatkan kesejahteraan masyarakat Desa;

j. Mengembangkan kehidupan sosial budaya masyarakat Desa;

k. Memanfaatkan teknologi tepat guna;

1. Mengoordinasi pembangunan Desa secara partsipatif;

m. Mewakili Desa didalam dan diluar pengadilan atau menunjuk kuasa; hukum untuk mewakilinya sesuai dengan ketentuan perundangundangan; dan

n. Melaksanakan wewenang lain yang sesuai dengan ketentuan peraturan perundang-undangan.

\section{Dana Desa}

Dana desa adalah dana yang bersumber dari APBN yang diperuntukkan bagi yang ditransfer melalui APBD kabupaten dan kota yang digunakan untuk membiayai penyelenggaraan pemerintahan, pelaksanaan pembangunan, pembinaan kemasyarakatan. Dana desa adalah salah satu issu krusial dalam undang-undang desa, 
penghitungan anggaran berdasarkan jumlah desa dengan mempertimbangkan jumlah penduduk, angka kemiskinan, luas wilayah, dan tingkat kesulitan geografis dalam rangka meningkatkan kesejahteraan dan pemerataan pembangunan desa. Karena issu yang begitu krusial, para senator menilai, penyelenggaraan pemerintahan desa membutuhkan pembinaan dan pengawasan, khususnya penyelenggaraan kegiatandesa.

Besaran Dana Desa setiap Desa sebagaimana dimaksud pada ayat (1) Peraturan Pemerintah Nomor 60 Tahun 2014 tentang Dana Desa yang Bersumber dari Anggaran Pendapatan dan Belanja Negara, dihitung berdasarkan jumlah penduduk desa, luas wilayah desa, angka kemiskinan Desa, dan tingkat kesulitan geografis. Jumlah penduduk Desa, luas wilayah Desa, dan angka kemiskinan Desa sebagaimana dimaksud pada ayat (2) dihitung denganbobot:

a. $30 \%$ (tiga puluh perseratus) untuk jumlah pendudukDesa;

b. $20 \%$ (dua puluh perseratus) untuk luas wilayah Desa;dan

c. $50 \%$ (lima puluh perseratus) untuk angka kemiskinanDesa.

Tingkat kesulitan geografis setiap Desa sebagaimana dimaksud pada ayat (2) digunakan sebagai faktor pengalihasil penghitungan sebagaimana dimaksud pada ayat (3). Besaran Dana Desa setiap Desa sebagaimana dimaksud pada ayat (1) dihitung dengan cara:

a. Dana Desa untuk suatu Desa = Pagu Dana Desa kabupaten/kota x [(30\% x persentase jumlah penduduk desa yang bersangkutan terhadap total penduduk desa di kabupaten/kota yang bersangkutan $)+(20 \% \mathrm{x}$ persentase luas wilayah desa yang bersangkutan terhadap total luas wilayah desa di kabupaten/kota yang bersangkutan $)+(50 \% \mathrm{x}$ persentase rumah tangga pemegang Kartu Perlindungan Sosial terhadap total jumlah rumah tangga desa di kabupaten/kota yang bersangkutan)]; dan

b. hasil penghitungan sebagaimana dimaksud pada huruf a disesuaikan dengan tingkat kesulitan geografis setiap desa.

c. Tingkat kesulitan geografis sebagaimana dimaksud pada ayat (4) ditentukan oleh faktor yang meliputi:

1. Ketersediaan pelayanandasar;

2. Kondisiinfrastruktur;

3. Transportasi;dan

4. Komunikasi desa kekabupaten/kota.

\section{Teori Pengelolaan}

Kata pengelolaan dapat disamakan dengan manajemen, berarti pula pengaturan atau pengurusan (Arikunto, 1993: 31). Menurut Stoner (dalam Kaho 1997: 228) manajemen dapat dilihat sebagai proses, yakni: proses perencanaan, pengorganisasian,pengarahan dan pengawasan. Maka, pengelolaan dapat diartikan sebagai suatu rangkaian pekerjaan atau usaha yang dilakukan oleh sekelompok orang untuk melakukan serangkaian kerja dalam mencapai tujuan tertentu. Menurut Fattah (2004: 1) dalam proses manajemen terlihat terlibat fungsi-fungsi pokok yang ditampilkan oleh seorang manajer atau pimpinan, yaitu perencanaan (planning), pengorganisasian (organizing), pemimpin (leading) dan pengawasan (controlling). Permendagri nomor 113 tahun 2014 pasal 1 ayat (7) menyebutkan bahwa Pengelolaan Keuangan Desa adalah keseluruhan kegiatan yang meliputi perencanaan, pelaksanaan, penatausahaan, pelaporan, dan pertanggungjawaban keuangandesa.

\section{Teori Pemberdayaan Masyarakat}

Pada hakikatnya pemberdayaan merupakan penciptaan suasana atau iklim yang memungkinkan potensi masyarakat berkembang(enabling). Logika ini didasarkan pada asumsi bahwa tidak ada masyarakat yang sama sekali tanpa memiliki daya. Setiap masyarakat pasti memiliki daya, akan tetapi kadang-kadang mereka tidak menyadari atau daya tersebut masih belum diketahui secara eksplisit. Oleh karena itu daya harus digali dan kemudian dikembangkan. Permendagri nomor 114 tahun 2014 pasal 1 ayat(12) Pemberdayaan Masyarakat Desa adalah upaya mengembangkan kemandirian dan kesejahteraan masyarakat dengan meningkatkan pengetahuan, sikap, keterampilan, perilaku, kemampuan, kesadaran, serta memanfaatkan sumber daya melalui penetapan kebijakan, program, kegiatan, dan pendampingan yang sesuai dengan esensi masalah dan prioritas kebutuhan masyarakat Desa.

\section{METODE PENELITIAN}

Dilihat dari obyek dan metode analisis yang digunakan, maka penelitian ini termasuk dalam tipe penelitian deskriptif kualitatif. Penetapan lokasi penelitianmerupakan hal yang sangat penting dalam mempertanggungjawabkan data yang di dapat. Dan demi menjawab permasalahan yang diidentifikasi peneliti maka dari itu, pada penelitian ini peneliti memilih lokasi di Desa Nekbaun, Kecamatan Amarasi Barat, Kabupaten Kupang. Fokus penelitian yang dilakukan dalam penelitian ini bagaimana Pengelolaan Dana Desa dalam Bidang Pemberdayaan di Desa Nekbaun, Kecamatan Amarasi Barat, Kabupaten Kupang. Informan yang dipilih adalah informan yang terlibat langsung serta memahami dan dapat 
memberikan informasi (gambaran) tentang pengelolaan Dana Desa, yaitu Pemerintah Desa/Tim Pelaksana Kegiatan. Sebagai informan dari unsur pemerintah desa, diwakili oleh Kepala Desa, Sekretaris Desa dan Bendahara, atau pihak lain yang berkaitan dalam pengelolaan DanaDesa.

Sumber data yang didapat peneliti yaitu data primer berupa data yang diperoleh peneliti berasal dari informan-informan yang diyakini mampu memberikan informasi terkait pengelolaan Dana Desa dalam Bidang Pemberdayaan di Desa Nekbaun seperti Kepala Desa, Sekretaris Desa dan Bendahara, Pihak lain yang berkaitan dalam pengelolaan Dana Desa, dan data sekunder yaitu data yang diperoleh peneliti berasal dari data APBDes Desa Nekbaun tahun 2017 dan juga Data Realisasi Anggaran terkait Dana Desa dan Bidang Pemberdayaan. Dalam rangka mengumpulkan data dan informasi yang valid dan akurat, pengumpulan data yang utama (untuk mendapatkan data primer) akan melakukan wawancara secara mendalam, yang dibantu dengan alat perekam(Handphone).

Analisis data kualitatif dilakukan secara interaktif dan berlangsung secara terus menerus sampai tuntas sehingga data mencapai kejenuhan. Dalam analisis kualitatif, data yang muncul berwujud kata-kata dan bukan rangkaian angka. Data itu mungkin telah dimunculkan dalam aneka macam cara (observasi, wawancara, intisari, dokumen,rekaman) dan yang biasanya diproses sebelum siap digunakan (melalui pencatatan, pengetikan, penyuntingan atau alih tulis., tetapi analisis kualitatif tetap menggunakan kata-kata, yang biasanya disusun ke dalam teks yang diperluas. Setelah peneliti melakukan data collection atau pengumpulan data, aktivitas selanjutnya dalam pengumpulan data yaitu data reduction, data display, dan conclusion drawing/verification.

\section{HASIL DAN PEMBAHASAN}

\section{Tahap Perencanaan}

Pada desa Nekbaun perencanaan diawali dengan menyusun RKP (Rencana Kerja Pemerintah) yang dilakssanakan dalam kegiatan Musrembangdes (Musyawarah Rencana Pembangunan Desa). RKP (Rencana Kerja Pemerintah) ini merupakan dasar penetapan APBDes sesuai dengan Permendagri Nomor 114 Tahun 2014 tentang Pedoman Pembangunan Desa Pasal 29 ayat (5).

Dalam Kegiatan Musrembangdes (Musyawarah Rencana Pembangunan Desa) juga ditetapkan tiga (3) program pada bidang pemberdayaan guna dimasukan dalam RKP (Rencana Kerja Pemerintah). Kegiatan Musrembagdes (Musyawarah Rencana Pembangunan Desa) ini juga mengikutsertakan masyarakat didalamnya. Namun terlihat kurangnya partisipasi masyarakat untuk ikut andil dalam kegiatan tersebut. Hal ini tentu tidak menjalankan asas partisipasi yang baik seperti yang ditulis dalam Permendagri113/2014.

\section{Tahap Penganggaran}

Penetapan anggaran dilakukan setelah selesainya penyusunan RKP (Rencana Kerja Pemerintah) dalam musyawarah bersama seluruh elemen masyarakat. Kemudian dilanjutkan dengan proses penyusunan APBDes. Terjadinya ketidaksesuaian anggaran yang dipaparkan oleh para aparat desa ini memberikan pertanyaan bagi peneliti yang mencurigai adanya praktek-praktek manipulasi dalam Pengelolaan Dana Desa di Desa Nekbaun berdasarkan pernyataan beberapa informan. Pernyataan tersebut juga didukung pada Tabel 1 dan Tabel 2 yang menunjukan Data APBdes Desa Nekbaun tahun 2017. Hal ini tentu belum menunjukan adanya asas transparansi yang menjadi salah satu asas dalam pengelolaan keuangan desa dalam Permendagri Nomor 113 Tahun 2014.

\section{Tahap Pelaksanaan}

Tahap pelaksanaan menunjukan hasil dari ketiga program pada Bidang Pemberdayaan tersebut yang sudah berdampak bagi masyarakat yaitu program Ternak Sapi. Semenjak direalisasikannya program ini masyarakat mengaku bahwa pendapatan mereka meningkat dari sebelumnya. Hal ini tentu berdampak baik bagi kesejahteraan masyarakat di Desa Nekbaun. Namun pada program BUMDES terlihat belum berjalan, kendalanya ditemukan pada kemampuan masyarakat desa yang masih minim dalam mengelolah anggaran yang jumlahnya tidak sedikit, kompetensi sumber daya manusia yang tidak menggambarkan pada proses kemandirian (Winarni, 1998: 76). Pada program BUMDES juga dicurigai adanya praktek-praktek manipulasi anggaran oleh beberapa oknum dikarenakan anggaran sebesar Rp 75.000.000,- tersebut sudahlah dicairkan. Sedangkan pada program Taman Eden terlihat adanya monopoli yang dilakukan oleh Kepala Desa dalam menjalankan program dan tidak mengikutsertakan masyarakat desa. Dengan demikian permasalahan yang ditemukan dalam proses pelaksanaan Pengelolaan Dana Desa di Desa Nekbaun, Kecamatan Amarasi Barat, Kabupaten Kupang ini tidak sesuai dengan Asas Transparansi, Partisipastif dan Akuntabel.

\section{Tahap Penatausahaan}

Tahap Penatausahaan pernyataan Kepala Desa Nekbaun dan Sekretaris Desa Nekbaun menjelaskan fakta yang terjadi di Desa Nekbaun mengenai laporan bulanan dari bendahara ke 
Kepala Desa. Dimana hal ini menunjukan bahwa tugas bendahara tidak dijalankan berdasarkan peraturan yang berlaku. Hal ini menunjukan tindakan aparat desa yang melanggar Asas Akuntabilitas dan Asas Tertib dan Disiplin belum berjalan sesuai dengan yang dituliskan dalam Permendagri Nomor 113 Tahun 2014 tentang, Pengelolaan Keuangan Desa. Tidak adanya pelatihan bagi aparatur desa untuk menunjang kapasitas dan kesadaran akan hukum juga menjadi penyebab terjadinya kelalaian aparatur Desa Nekbaun, Kecamatan Amarasi Barat, Kabupaten Kupang dalam menjalankan tugas dan tanggungjawabnya masing-masing.

\section{Tahap Pelaporan dan Pertanggungjawaban}

Tahap pelaporan dan pertanggungjawaban menunjukan bahwa bahwa adanya kelalaian dari Kepala Desa Nekbaun yang menjalankan tugasnya dalam pasal 37 ayat (1), Pemendagri Nomor 113 Tahun 2014. Keterlambatan pencairan Dana Desa juga menjadi kendala yang besar dalam proses pengelolaan Dana Desa juga perealisasian program. Hal ini juga menunjukan belum berjalannya asas akuntabilitas juga asas tertib dan displin yang belum dijalankan secara baik dari para aparatur Desa Nekbaun. Kelemahan kompetensi para aparatur menjadi penyebab terjadinya hal yang tidak sesuai pada tahap pelaporan dan pertanggungjawaban. Asas Transparansi juga menjadi kendala bagi masyarakat Desa Nekbaun. Menurut pengamatan dan beberapa hasil wawancara yang diperoleh peneliti, sekarang memang sudah disediakan informasi pada papan baliho yang dipasang di Kantor Desa dan daerah sekitaran Desa Nekbaun namun hal tersebut juga nyatanya kurang memberikan pengetahuan bagi masyarakatdesadikarenakan anggaran yang keluar dan masuk tiap bulan, tiap triwulan, dan tiap semester tidak pernah di informasikan kepada masyarakat DesaNekbaun.

Hasil penelitian diatas menunjukan bahwa di Desa Nekbaun, Kecamatan Amarasi Barat, Kabupaten Kupang belum memenuhi asas-asas yang tertera dalam Permendagri 113/2014 yaitu, Asas Partisipatif, Transparan, Akuntabel, Asas Tertib dan Disiplin.

\section{KESIMPULAN}

Pengelolaan Dana Desa dalam Bidang Pemberdayaan di Desa Nekbaun, Kecamatan Amarasi Barat, Kabupaten Kupang belum sesuai dengan pelaksanaan pengelolaan Dana Desa dalam Bidang Pemberdayaan yang tertuang dalam Peraturan Menteri Dalam Negeri Nomor 113 Tahun 2014 tentang pengelolaan keuangan desa serta asas-asas yang berlaku di dalamnya yaitu asas partisipatif, asas transparansi, akuntabilitas dan asas tertib dan disiplin sehingga timbulnya berbagai masalah dalam pelaksanaan program di bidang pemberdayaan diantaranya Taman Eden dan BUMDES. Lemahnya kemampuan aparatur desa dalam mengelola dana desa secara baik dan benar menjadi masalah bagi proses pengelolaan dana desa dalam bidang pemberdayaan. Kurangnya partisipasi masyarakat juga menjadi kendala dalam pengelolaan dana desa di desaNekbaun.

Pemerintah Desa harus mengadakan sosialisasi pembinaan dan pelatihan secara langsung dan menyeluruh tentang peraturan menteri dalam Negeri Nomor 113 tahun 2014 kepada Aparatur Pemerintah Desa dan seluruh tokoh masyarakat yang terlibat dalam Pengelolaan Dana Desa Desa Dalam Bidang Pemberdayaan. Pengelolaan Dana Desa harus berdasarkan pada Petunjuk Pelaksanaan yang berlaku serta harus memenuhi asas-asas yang telah di tetapkan yaitu, Asas Transparan, Akuntabel, Partisipan Serta Dengan Tertib Dan Disiplin anggaran dengan memberikan bimbingan secara terus-menerus diharapkan setiap perangkat desa lebih mengetahui tugas dan fungsinya masing-masing. Bagi seluruh Masyarakat Desa Nekbaun terutama yang menerima bantuan dalam bidang pemberdayaan seperti Ternak Sapi, BUMDES, dan Taman Eden diharapkan lebih aktif dan partisipatif untuk ikut andil dalam Pengelolaan Dana Desa.

\section{DAFTAR PUSTAKA}

Arikunto Suharsimi. 2013. Manajemen Penelitian. Jakarta: PT. Raja Grafindo Persada.

Dokumen APB-Desa Nekbaun Kecamatan Amarasi Barat Kabupaten Kupang, 2017.

Dokumen APB-Desa Nekbaun Kecamatan Amarasi Barat Kabupaten Kupang, 2018.

Dokumen Data Umum dan Data Kependudukan Desa Nekbaun, Kecamatan Amarasi Barat, Kabupaten Kupang, Februari 2018.

Dokumen Laporan Realisasi Anggaran Desa Nekbaun, Kecamatan Amarasi Barat, Kabupaten Kupang Tahun 2017.

Fatta, Nanang. 2004. Konsep Manajemen Besrbasis Sekolah (MBS) dan Dewan Sekolah. Bandung : Pustaka BaniQuraisy.

Follet, Mary Parker. 1999. Visionary Leadership andStrategicManagement.

Hasniati.2016.Model Akuntabilitas Pengelolaan Dana Desa. Jurnal Analisis Kebijakan dan 
Pelayanan Publik. Universitas Diponegoro.

Kartohadikoesoemo, Soetardjo. 2004. DESA. Jakarta: Balai Pustaka.

Karimah, Faizatul. Saleh, Choirul. dan Wanusmawatie, Ike. (2014). Pengelolaan Alokasi Dana Desa Dalam Pemberdayaan Masyarakat (Studi pada Desa Deket Kulon Kecamatan Deket Kabupaten Lamongan). Jurnal Administrasi Publik. UniversitasBrawijaya.

Prasetyanigtyas, Feni Yudanti. dan Sulandari, Susi.2014. Analisis Pengelolaan Alokasi Dana Desa Dalam Pemberdayaan Masyarakat Desa Karangluhur Kabupaten Wonosobo.Tesis Program Pasca Sarjana Ilmu Departemen Administrasi Publik, Fisip Undip. (tidak dipublikasikan)

Putra, Chandra Kusuma. Pratiwi, Ratih Nur dan Suwondo.(2014). Pengelolaan Alokasi Dana Desa Dalam Pemberdayaan Masyarakat Desa (Studi Pada Desa Wonorejo Kecamatan Singosari Kabupaten Malang). Jurnal Administrasi Publik. UniversitasBrawijaya.

Peraturan Menteri Desa, Pembangungan Daerah Tertinggal, dan Transmigrasi No. 21 Tahun 2016 tentang Penetapan Prioritas Penggunaan Dana Desa Tahun 2016.

Peraturan Pemerintah Nomor 60 Tahun 2014 tentang Dana Desa yang Bersumber dari Anggaran Pendapatan dan Belanja Negara

Peraturan Menteri Dalam Negeri Republik Indonesia Nomor 113 Tahun 2014 tentang Pengelolaan Keuangan Desa

Peraturan Menteri Dalam Negeri Republik Indonesia Nomor 114 Tahun 2014 tentang Pedoman Pembangunan Desa

Riskawati. Amaliah, Tri Handayani. dan Lukum,Amir. (2016).Analysis Of Local Government Performance In Managing Distribution Of Village Funds (Case Study In Kalia Village, Talatako Sub-District, Tojo Una-Una District). Journal Accounting and Business Education. Universitas NegeriGorontalo.

Undang-undang Republik Indonesia Nomor 6 Tahun 2014 tentang Desa.

Winarni, Tri. 1998. Memahami Pemberdayaan Masyarakat Desa Partisipatif dalam Orientasi Pembangunan Masyarakat Desa

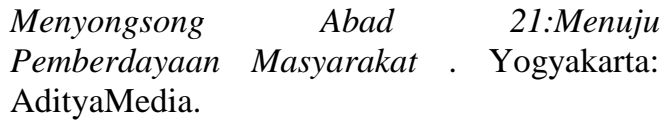

Yayuk Yulianti.2003. Sosiologi Pedesaan. Yogyakarta : Lapera Pustaka Utama. 
